\title{
The association between homelessness, hepatitis $C$ risk factors and hepatitis C exposure among people who inject drugs in England, Wales and Northern Ireland: protocol for a cross-sectional study
}

Authors: Dr. Binta Sultan, Dan Lewer

Collaborative Centre for Inclusion Health, University College London

1-19 Torrington Place, London WC1E 7HB

6 March 2019

\section{Research questions}

- Among people who inject drugs, do those with experience of homelessness differ in terms of risky injecting practices, contact with harm reduction services and incarceration?

- Among people who inject drugs, do those with experience of homelessness have a higher prevalence of hepatitis $\mathrm{C}$ exposure?

- Is any difference in Hepatitis $\mathrm{C}$ exposure comparing homeless and non-homeless PWID explained by differences in injecting practices, contact with harm reduction, and incarceration?

\section{Background}

Estimates of the prevalence of hepatitis $\mathrm{C}$ infection among homeless people range from $3.9 \%$ to $36.2 \%$, and in most countries the raised prevalence is primarily associated with injecting drug use [1]. Among people who inject drugs (PWID), there is evidence that homelessness and unstable housing increase the risk of blood-borne virus infection [2].

There are a number of possible reasons for this. Homelessness is associated with public injecting, which can lead to a sense of urgency, reduced care, reduced access to clean water and washing facilities, reduced access to harm reduction interventions and consequently increased risk of bacterial and viral infections [3-7]. People who experience homelessness may also use drugs that are associated with increased risk. For example, the Needle Exchange Survey Initiative in Scotland reported that homelessness was associated with injecting novel psychoactive substances, and that using these drugs was associated with increased risk of HCV exposure [8]. A modelling study using surveys of PWID showed that $60 \%$ of hepatitis $C$ infections could be attributed to homelessness and use of crack cocaine [9], however this used data from 2012.

Most of the more recent data about the risk of hepatitis $C$ in this population are from smaller studies in the UK [9] and from studies outside the UK [11]. There is little recent evidence from the UK of the hepatitis $\mathrm{C}$ risk in those who experience homelessness and inject drugs and which specific risk factors are associated with homelessness.

This study is timely, considering it is in the context of NHS England's strategy for hepatitis C elimination by 2025 . A better understanding of hepatitis $C$ exposure and risk factors associated with homelessness can provide evidence for health promotion policies. This study will inform the development of strategies to achieve the target of hepatitis $C$ elimination in England in the populations that are hardest to reach with existing service models. 


\section{Methods}

We plan to use secondary anonymised data from the Unlinked Anonymous Monitoring Survey of HIV and Viral Hepatitis among People Who Inject Drugs (UAMS) [12].The survey is funded, developed and managed by Public Health England and has run annually since 1990, with the latest available data from 2017. People who inject drugs are recruited via a sample of specialist drug services (such as needle and syringe programmes and addiction treatment centres) throughout England, Wales and Northern Ireland.

We plan to use data from the 2012-2017 surveys to achieve a large sample size without using data that is too old or survey questions that may have changed over time. The total number of participants was 17,813 . We will exclude participants: who have not injected in the past year, who have done the survey before, or who are aged under 16 or over 64 , resulting in a dataset of 11,371. Data from the 2018 survey may be added when it becomes available (anticipated May 2018).

A full list of variables envisaged in this study is given in the appendix.

\section{Descriptive analysis}

We will report the prevalence of risk factors, protective factors and incarceration by ever-homeless and never-homeless status, using direct standardisation to adjust for possible differences in the age and sex profile of the groups (with never-homeless group as the reference).

\section{Primary analysis}

We will use logistic regression with Hepatitis $\mathrm{C}$ exposure (measured as antibody positive in a dried blood spot test) as the dependent variable and homelessness as the main independent variable. Based on existing literature, we anticipate that homelessness will be positively associated with Hepatitis $\mathrm{C}$ exposure. We will add blocks of risk factors and protective factors to test whether these variables explain any difference in Hepatitis $\mathrm{C}$ exposure. We anticipate that risk factors will be added as shown in table 1.

Table 1. Example results table: odds ratio of Hepatitis $C$ exposure (outcome) comparing everhomeless and never-homeless PWID

\begin{tabular}{|c|c|c|c|}
\hline Model & Odds ratio & $95 \% \mathrm{Cl}$ & \% Change in OR \\
\hline 1: age + sex & 1.5 & $1.2-1.9$ & - \\
\hline 2: model $1+$ frequency and duration & 1.3 & $1.1-1.8$ & $13 \%$ \\
\hline \multicolumn{4}{|l|}{ 3. model $1+$ drugs injected } \\
\hline \multicolumn{4}{|l|}{ 4. model $1+$ sharing } \\
\hline \multicolumn{4}{|l|}{ 5. model $1+$ high risk injecting sites } \\
\hline \multicolumn{4}{|l|}{ 6. model $1+$ all injecting risk variables } \\
\hline \multicolumn{4}{|l|}{ 7. model $1+$ uses needle exchanges } \\
\hline \multicolumn{4}{|l|}{ 8. model $1+$ opiate substitution therapy } \\
\hline \multicolumn{4}{|l|}{ 9. model $1+$ all protective factors } \\
\hline \multicolumn{4}{|l|}{ 10. model $1+$ incarceration } \\
\hline 11. fully adjusted & & & \\
\hline
\end{tabular}


Secondary analysis 1: joint effects of homelessness and incarceration on hepatitis C exposure

We will create a new variable that places participants in four groups: never homeless and never incarcerated (reference group); ever-homeless and never incarcerated; never-homeless and ever incarcerated; and ever-homeless and ever-incarcerated. We will fit a logistic regression model with hepatitis $\mathrm{C}$ exposure as the dependent variable and the new variable as the main exposure, adjusting for age and sex. This analysis will show whether homelessness and incarceration interact on the risk of hepatitis $\mathrm{C}$. We will also fit a model with an interaction term and use a likelihood ratio test (comparing with nested model 10 in table 1) to report the significance of the interaction.

Secondary analyses 2: among those with hepatitis $C$ exposure, how does care differ between homeless and non-homeless PWID?

Among those with evidence of hepatitis $C$ exposure, we will report the proportions that have tested, know their status and have had contact with a hepatitis specialist. These proportions will be stratified by homelessness status and presented in a 'cascade'. Differences between proportions at each stage will be tested using chi-square tests. The cascade will be presented for the whole sample, and also stratified by (a) participants in survey years pre- and post-2014, to see if development of direct acting antiviral therapy is associated with improved diagnosis and care and (b) those with experience of incarceration, to see if opt-out testing in prisons is associated with improved diagnosis and care.

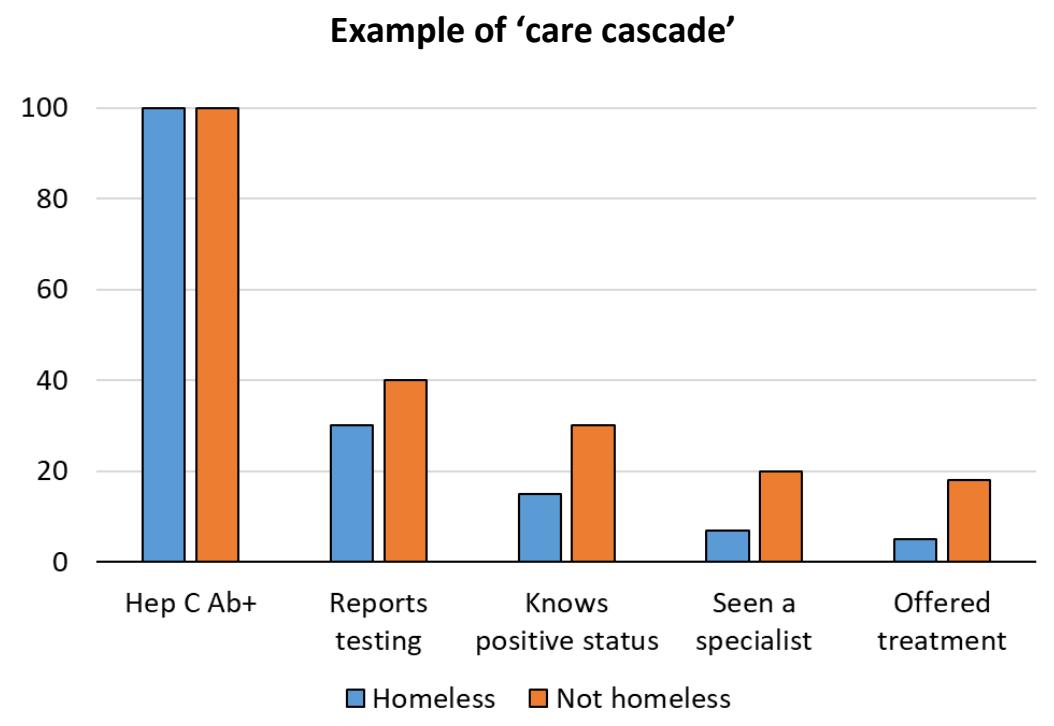

\section{Ethics}

UAMS has multisite ethics approval. This will be a secondary analysis of anonymised data and further ethics consideration is not required. 


\section{References}

1 Beijer U, Wolf A, Fazel S. Prevalence of tuberculosis, hepatitis C virus, and HIV in homeless people: a systematic review and meta-analysis. Lancet Infect Dis 2012;12:859-70. doi:10.1016/S14733099(12)70177-9

2 Ragonnet-Cronin M, Jackson C, Bradley-Stewart A, et al. Recent and Rapid Transmission of HIV Among People Who Inject Drugs in Scotland Revealed Through Phylogenetic Analysis. J Infect Dis 2018;217:187582. doi:10.1093/infdis/jiy130

3 Galea S, Vlahov D. Social Determinants and the Health of Drug Users: Socioeconomic Status, Homelessness, and Incarceration. Public Health Rep 2002;117:S135-145.

4 Barrow SM, Herman DB, Córdova $\mathrm{P}$, et al. Mortality among homeless shelter residents in New York City. Am J Public Health 1999;89:529-34. doi:10.2105/AJPH.89.4.529

5 Corneil T, Kuyper L, Shoveller J, et al. Unstable housing, associated risk behaviour, and increased risk for HIV infection among injection drug users. Health Place 2006;12:79-85. doi:10.1016/j.healthplace.2004.10.004

6 Rhodes T, Kimber J, Small W, et al. Public injecting and the need for 'safer environment interventions' in the reduction of drug-related harm. Addiction 2006;101:1384-93. doi:10.1111/j.1360-0443.2006.01556.x

7 Rhodes T, Watts L, Davies S, et al. Risk, shame and the public injector: A qualitative study of drug injecting in South Wales. Soc Sci Med 2007;65:572-85. doi:10.1016/j.socscimed.2007.03.033

8 McAuley A, Yeung A, Taylor A, et al. Emergence of Novel Psychoactive Substance injecting associated with rapid rise in the population prevalence of hepatitis C virus. Int J Drug Policy 2019;66:30-7. doi:10.1016/j.drugpo.2019.01.008

9 Platt L, Sweeney S, Ward Z, et al. Assessing the impact and cost-effectiveness of needle and syringe provision and opioid substitution therapy on hepatitis $C$ transmission among people who inject drugs in the UK: an analysis of pooled data sets and economic modelling. Public Health Res 2017;5:1-118. doi:10.3310/phr05050

10 Aldridge RW, Hayward AC, Hemming S, et al. High prevalence of latent tuberculosis and bloodborne virus infection in a homeless population. Thorax 2018;73:557-64. doi:10.1136/thoraxjnl-2016-209579

11 Aldridge RW, Story A, Hwang SW, et al. Morbidity and mortality in homeless individuals, prisoners, sex workers, and individuals with substance use disorders in high-income countries: a systematic review and meta-analysis. The Lancet 2018;391:241-50. doi:10.1016/S0140-6736(17)31869-X

12 Public Health England. Unlinked anonymous HIV and viral hepatitis monitoring among PWID: 2018 report. Health Prot Rep

2018;12:15.https://assets.publishing.service.gov.uk/government/uploads/system/uploads/attachment_dat a/file/729614/hpr2718_uam-pwid.pdf (accessed 11 Feb 2019). 
Appendix: UAMS variables

\begin{tabular}{|c|c|c|c|}
\hline Group & Variable & $\begin{array}{l}\text { Question } \\
\text { number ( } 2018 \\
\text { survey) }\end{array}$ & Levels \\
\hline \multirow[t]{2}{*}{ Survey } & Year of survey & NA & Pre vs. post 2014 (i.e. 2012/13/14; 2015/16/17) \\
\hline & $\begin{array}{l}\text { Government Office } \\
\text { Region }\end{array}$ & NA & London / South East / Wales, etc. \\
\hline \multirow[t]{2}{*}{ Demographics } & Age group & 2 & $16-24 / 25-34 / 35-44$ / 45-54 / 55-64 \\
\hline & Sex & 3 & Male / Female \\
\hline \multirow[t]{7}{*}{ Injecting risk } & $\begin{array}{l}\text { Duration of } \\
\text { injecting (years) }\end{array}$ & $1 b, 2,10$ & We will calculate a continuous variable \\
\hline & $\begin{array}{l}\text { Injected in the past } \\
\text { month }\end{array}$ & 11 & Yes / No \\
\hline & Drugs injected & $10 / 11$ & $\begin{array}{l}\text { All options. We will process into } 3 \text { binary variables: opiates } \\
\text { (heroin / methadone), stimulants (crack, cocaine, amphetamine), } \\
\text { other (ketamine, mephedrone, other), and then to a single } \\
\text { variable showing combinations (e.g. opiates+stimulants) }\end{array}$ \\
\hline & $\begin{array}{l}\text { Received used } \\
\text { equipment - past } \\
\text { year/month }\end{array}$ & $10 / 11$ & Yes / No \\
\hline & $\begin{array}{l}\text { Ever received used } \\
\text { equipment }\end{array}$ & 6 & Yes / No \\
\hline & $\begin{array}{l}\text { High risk injecting } \\
\text { sites }\end{array}$ & 11 & $\begin{array}{l}\text { All options. We will process into a binary variable: Yes (hands, } \\
\text { groin, feet, neck) / No / NA (for those not injecting in past } 28 \\
\text { days) }\end{array}$ \\
\hline & $\begin{array}{l}\text { Frequency of } \\
\text { injecting }\end{array}$ & 11 & Continuous - number of days in the past month \\
\hline Homelessness & Ever homeless & 22 & No / Yes more than a year ago / Yes past year / Yes currently \\
\hline \multirow[t]{4}{*}{ Hep C } & $\begin{array}{l}\text { Hep C antibody + } \\
\text { from dried blood } \\
\text { spot }\end{array}$ & NA & Positive / negative \\
\hline & Hep $C$ test in past & 20 & Yes / No \\
\hline & $\begin{array}{l}\text { Result of last Hep C } \\
\text { test (self-report) }\end{array}$ & 20 & $\begin{array}{l}\text { Positive / Negative / Awaiting } \\
\text { (For } 2017 \text { onward, current/past/not sure will be grouped as } \\
\text { positive) }\end{array}$ \\
\hline & $\begin{array}{l}\text { Seen hepatitis } \\
\text { nurse / doctor }\end{array}$ & 20 & Yes - offered treatment / Yes - not offered treatment / No \\
\hline \multirow[t]{3}{*}{$\begin{array}{l}\text { Protective } \\
\text { factors }\end{array}$} & $\begin{array}{l}\text { Ever prescribed } \\
\text { maintenance drug }\end{array}$ & 7 & Yes / No \\
\hline & $\begin{array}{l}\text { Needle exchange } \\
\text { coverage }\end{array}$ & 5 & $\begin{array}{l}\text { Number of needles collected in past month. From } 2017 \text {, } \\
\text { calculated from number of visits * typical number collected. } \\
\text { Anticipate using simpler variable (used in past year) because (a) } \\
\text { this is more consistent; (b) high coverage may reflect risk (a lot of } \\
\text { injections) or protection (a lot of clean needles) }\end{array}$ \\
\hline & $\begin{array}{l}\text { Used needle } \\
\text { exchange in past } \\
\text { year }\end{array}$ & 5 & Yes / No \\
\hline \multirow[t]{2}{*}{ Incarceration } & $\begin{array}{l}\text { Number of times in } \\
\text { prison }\end{array}$ & 21 & $\begin{array}{l}\text { Continuous variable }(0+) \text {, created from 'ever in prison' (yes / no) } \\
\text { and number of times in prison }\end{array}$ \\
\hline & $\begin{array}{l}\text { Ever injected in } \\
\text { prison }\end{array}$ & 21 & Yes / no \\
\hline
\end{tabular}

